Katarzyna Bednarska

Katedra Języków Specjalistycznych

oraz Komunikacji Międzykulturowej

Uniwersytet Łódzki

katarzyna.bednarska@uni.lodz.pl

\title{
MEDIA A PAMIĘĆ ZBIOROWA - ANALIZA WSPÓŁCZESNEGO SŁOWEŃSKIEGO DYSKURSU MEDIALNEGO DOTYCZĄCEGO GROBU MASOWEGO W HUDEJ JAMIE
}

W 2009 roku w opuszczonej kopalni węgla Laško we wsi Huda Jama słoweńscy górnicy odkryli pochodzący z czasów II wojny światowej grób masowy. Kopalnię zabetonowano w roku 1945, kiedy na rozkaz Komunistycznej Partii Jugosławii zamordowano w niej setki niemieckich kolaborantów. O masowym grobie w Hudej Jamie wspominano przed 2009 rokiem, jednak nie podjęto żadnych działań.

Celem niniejszego artykułu jest przedstawienie, jak media tworzą pamięć zbiorową, który dyskurs jest dominujący oraz jakie znaczenie poszczególne czasopisma lub serwisy przypisują zdarzeniom powojennym. Wykorzystując ten typ analizy, trudno przedstawić, jaki wpływ badane artykuły mają na czytelnika. Można natomiast stwierdzić, przez pryzmat którego z dominujących dyskursów współczesne media przedstawiają II wojnę światową oraz w jaki sposób przeciwstawne dyskursy walczą o legitymizację pamięci. Metodą wykorzystaną do zbadania interesującego mnie problemu jest analiza dyskursu medialnego.

Człowiek jest powiązany z przeszłością dzięki kategoriom i schematom obecnym w kulturze - tworzą one struktury, poprzez które odbiera wydarzenia historyczne (Burke 1989: 98). Ponieważ te kategorie i schematy najczęściej są tworzone nieświadomie, pamięć ma niekiedy charakter wypaczony (Burke 2008: 67-68). Związek z przeszłością to zarówno więzi rodzinne, jak i pamięć o osobach oraz wydarzeniach, które odegrały ważną rolę w kształtowaniu się tożsamości narodowej. 
Zdaniem Barbary Misztal główną społecznością pamięci jest naród. Jego ciągłość opiera się na wizjach odpowiedniej przeszłości i prawdopodobnej przyszłości. Przeszłość jest niezbędna do tworzenia wyobrażeń o narodzie, co często jest domeną ruchów nacjonalistycznych, które propagują ideologie, odwołując się właśnie do wspólnych wspomnień. Ruchy te zawdzięczają więc swój sukces fenomenowi pamięci, który wykorzystują, aby stworzyć poczucie ciągłości między pokoleniami.

Podczas formowania się wspólnot rozwija się także dyskurs historyczny, który jest do danej grupy dostosowany w zależności od jej wymagań i potrzeb. Aby społeczność stworzyła wspólną tożsamość, potrzebuje wspólnych celów (przyszłość) oraz punktów referencyjnych (przeszłość). W ten sposób najpierw rozwija, a następnie zachowuje taką pamięć zbiorową, która najlepiej odpowiada wybranemu obrazowi przeszłości, czyli pamięć, którą Misztal definiuje jako „a group's representation of its past, both the past that is commonly shared and the past that is collectively commemorated, that enacts and gives substance to that group's identity, its present conditions and its vision of the future" (Misztal 2003: 158).

Jak zauważył francuski socjolog Maurice Halbwachs, „umysł odtwarza swoje wspomnienia pod presją społeczeństwa” (Halbwachs 2008: 168). Badacz ten twierdził także, że pamięć zbiorowa znacznie różni się od pamięci historycznej, ponieważ jest ciągłym biegiem myśli, w którym zaciera się wszystko to, co nie jest żywe w świadomości wspólnoty (zob. Król 2008: XXVII). Charakteryzuje się też silniejszą niż pamięć historyczna zależnością od teraźniejszości. Ponadto pamięci zbiorowych jest tyle, ile wspólnot, historia natomiast jest jedna. Rozwijając teorię pamięci zbiorowej, Halbwachs zauważył także, że pamięć nie należy do jednostki, lecz jest częścią narracji zbiorowej, niejako zapożyczonej z wypowiedzi innych członków społeczności. Kolektywność pamięci wzmacniana jest poprzez wszelkiego rodzaju uroczystości, komemoracje itp., podczas których wspomina się ważne dla danej społeczności wydarzenia. Poprzez taką rekonstrukcję przeszłości można dokładnie opowiedzieć historię, choć nie zawsze jest to historia w pełni prawdziwa, ponieważ „społeczeństwo nie tylko od czasu do czasu zmusza ludzi do odtwarzania w myśli wydarzeń z ich dawnego życia, lecz także do ich poprawiania, okrawania i uzupełniania" (Halbwachs 2008: 171).

Drugą częścią procesu budowy spójnej pamięci zbiorowej jest zapominanie. Pisanie narracji historycznej zawsze wiąże się z koniecznością eliminacji niektórych elementów, należy zatem „zapomnieć o wydarzeniach stanowiących zagrożenie dla jedności oraz pamiętać o bohaterach i dniach chwały" (Misztal 2003: 17, tłum. w1.).

Zarówno pamiętanie, jak i zapominanie podlegają zmianom, które Pierre Nora uznaje za najbardziej stałe i ciągłe zjawisko we współczesnym świecie 
(Nora 2010). Coraz szybciej postępujące zmiany przesuwają zdarzenia w przeszłość, teraźniejszość więc szybko staje się przeszłością:

Przemiana ta przybrała rozmaite formy: krytyka oficjalnych wersji historii, odkrywanie zepchniętych w niepamięć fragmentów dziejów, rewindykowanie śladów przeszłości wymazanej lub skonfiskowanej, kult korzeni (roots) i rozwój badań genealogicznych, gorączka wszelkiego rodzaju obchodów rocznicowych, sądowe rozrachunki z przeszłością, mnożenie się najrozmaitszych muzeów, zwiększona uwaga poświęcana przechowywaniu archiwaliów i udostępnianiu ich w celu konsultacji [... ]. Można powiedzieć, że jakaś gę̨binowa fala pamięci rozlała się ostatnio po świecie, wszędzie wiążąc ze sobą bardzo ściśle wierność dla rzeczywistej lub wyobrażonej przeszłości z poczuciem przynależności, świadomość zbiorową ze świadomością jednostkową, pamięć z tożsamością (Nora 2010: 134).

Gorączka rocznicowa, o której pisze Nora, obejmuje także jubileusze zdarzeń, które nie mają przełomowego charakteru, a ich obchodzenie może zostać uznane za niewłaściwe czy nieetyczne. Do takich wydarzeń należy odkrycie masowych grobów w Hudej Jamie. Nie ulega wątpliwości, że zachowanie pamięci o II wojnie światowej jest istotne, zaś celebrowanie jej rozpoczęcia, zakończenia czy też - jak to mam miejsce w przypadku Słowenii - dnia, w którym część społeczeństwa zdecydowała się przeciwstawić okupantowi (27 kwietnia $\mathrm{w}$ Słowenii jest świętem narodowym ${ }^{1}$ ) odgrywa dużą rolę w kształtowaniu tożsamości narodowej, jednak we współczesnym świecie w wyniku rewindykowania przeszłości dochodzi do powstawania coraz to nowych rocznic. Naturalnym nośnikiem informacji o tego typu jubileuszach są media.

Powojenne mord $\mathrm{y}^{2}$ przez długi czas nie mogły być przedmiotem dyskusji publicznej. Autorem pierwszych doniesień był jeden z bohaterów walki narodowowyzwoleńczej, słoweński pisarz Edvard Kocbek, który już w latach

127 kwietnia 1941 roku w Lublanie utworzono Front Przeciwimperalistyczny (Protiimperialistična fronta, PIF), który po dwóch miesiącach zmienił nazwę na Front Wyzwoleńczy Narodu Słoweńskiego (Osvobodilna fronta slovenskega naroda, OF). W skład PIF wchodzą trzy duże ugrupowania: Komunistyczna Partia Słowenii (Komunistična partija Slovenije, KPS), chrześcijańscy socjaliści, lewicowa część organizacji Sokol. Swoją reprezentację mieli także przedstawiciele elity kulturalnej Słowenii. W późniejszym czasie do PIF dołączyło jeszcze kilkanaście mniejszych ugrupowań.

2 Na potrzeby niniejszej pracy używam ogólnie przyjętej terminologii, jednak termin „mordy powojenne” uważam za nieadekwatny, gdyż do ludobójstwa doszło już po formalnym zakończeniu II wojny światowej. Było ono jednak efektem działań wojennych i decyzji podejmowanych przez wszystkie zaangażowane w konflikt strony, właściwszy termin to zatem „mordy wojenne”. 
siedemdziesiątych XX wieku zwracał uwagę na przemilczany fragment historii $^{3}$, jednak jego teksty nie zostały opublikowane. Dopiero dwie dekady później, czyli po upadku komunizmu, zaczęto otwarcie mówić o mordach i zbiorowych mogiłach. W słoweńskiej debacie publicznej, w której dotychczas istniał jedynie pozytywny wizerunek Frontu Wyzwoleńczego, pojawil się nowy dyskurs historyczny, przedstawiający Front jako oprawcę. Dziś polaryzacja zdań na temat walki z okupantem jest tak silna, że media i politycy mogą wykorzystywać ją do osiągania swych celów.

$\mathrm{W}$ dziesiątą rocznicę odkrycia grobów masowych w HudejJamie w Słowenii z nową siłą powróciła dyskusja dotycząca wydarzeń powojennych. Analizowane przeze mnie artykuły pochodzą z portali tygodników „Reporter” i „Demokracija”, dzienników „Dnevnik” i „Delo” (dwa artykuły), czasopism internetowych „Ćasnik” i „Domovina” oraz portali informacyjnych „Nova 24” oraz „e-Maribor”. Portale te zamieścily artykuły dotyczące historii znaleziska oraz wywiady ze specjalistami, jednak historia zeszła na drugi plan, ponieważ informacje opierały się głównie na komentarzach o charakterze ideologicznym i wartościującym. Należy podkreślić, że w lewicowym tygodniku „Mladina” nie znaleziono żadnej wzmianki o okrągłej rocznicy, lewicujący dziennik „Dnevnik” umieścił zaś jedynie krótką informację dotyczącą wypowiedzi słoweńskiego historyka Jožego Dežmana, który stwierdził, że były prezydent Słowenii Danilo Türk popełnił polityczne samobójstwo, kiedy powiedział, że temat Hudej Jamy jest drugoplanowy („Dnevnik”). Wyjęta z kontekstu wypowiedź prezydenta przez dziesięć lat była hasłem często wykorzystywanym przez prawicowe media w celu zdyskredytowania nie tylko jego, lecz także pozostałych opcji politycznych. Z okazji rocznicy odkrycia masowych grobów do niefortunnej wypowiedzi odniosły się także „Časnik” i „Demokracija”:

(1) Takrat je tedanji predsednik dr. Danilo Turk to strašno odkritev ocenil za drugorazredno temo [Wtedy ówczesny prezydent dr Danilo Turk określił to przerażające odkrycie jako drugoplanowe $\left.{ }^{4}\right]$;

${ }^{3}$ W Socjalistycznej Federacyjnej Republice Jugosławii dominował dyskurs słoweńskiego dowództwa politycznego i wojskowego. Natomiast dyskurs dolnych warstw hierarchii wojskowej, czyli samych partyzantów, którzy wysyłani byli do walki, nie mógł się ujawnić. Nie interesowano się problemami, słabościami i strachem zwykłych ludzi, przez co dyskurs partyzancki stał się suchy, wyzuty z emocji. Partyzanci byli przedstawiani jako bohaterowie, nikt jednak nie pochylał się nad ich ewentualnymi traumami, co pokutuje do dziś - niektóre media traktują partyzantów niemalże jak maszyny do zabijania niewinnych obywateli oraz stawiają znak równości między komunistami i partyzantami.

${ }^{4}$ Tłumaczenie wszystkich cytatów pochodzi ode mnie. 
je bilo za nekatere odkritje tisoče zverinsko pobitih prehudo, za nekatere streznitev, za takratnega predsednika dr. Danila Turka pa nekaj dni kasneje ob dnevu žena drugorazredna tema [dla niektórych odkrycie tysięcy zamordowanych było tragedią, dla innych otrzeźwieniem, a dla ówczesnego prezydenta dr. Danila Turka, po kilku dniach w Dzień Kobiet - tematem drugoplanowym].

oraz Domovina, która zatytułowała artykuł 10 let od pojava „drugorazredne teme", a zatem można wywnioskować, że wypowiedź prezydenta jest według tego portalu ważniejsza niż same masowe groby.

Dla autorów publikujących w portalach „Časnik” i „Domovina” dziesiąta rocznica stała się ponadto pretekstem do przedstawienia negatywnej opinii o słoweńskiej telewizji oraz o samej Słowenii, do szukania spisku, do obrażenia lewicy:

(2) to ni bila dovolj zanimiva tema, da bi jo zgoraj omenjeni mediji ali RTV spremljali - in to ne glede na to, da je RTV javna inštitucija, ki je zavezana neodvisnosti in nepristranskosti («Časnik») [temat nie był wystarczająco interesujący, żeby pojawić się w wyżej wymienionych mediach lub RTV - i to bez względu na fakt, że RTV jest instytucją publiczną, zobowiązaną do niezależności i bezpartyjności];

(3) Slovenija zaradi svoje večkrat pokazane nelojalne drže odgovornih (pranje iranskega denarja, tesne stike $\mathrm{z}$ Rusijo in njenim predsednikom Putinom v času evropskih sankcij) zapravila svoj prej kar precejšen prestiż ( «Časnik») [Słowenia, w wyniku swojego wielokrotnie pokazywanego braku lojalności odpowiedzialnych osób (pranie irańskich pieniędzy, bliskie kontakty z Rosją i jej prezydentem Putinem podczas sankcji europejskich), straciła swój znaczny prestiż];

(4) Upam, da je pred nekaj dnevi res šlo samo za tehnično napako, vsaj taka je bila razlaga odgovornih po intervenciji, ko naenkrat dostop do oddaje z Lidijo Drobnič iz tujine ni bil mogoč. Mnogi potomci žrtev evidentiranih med- in povojnih morišč, pa tudi drugih kršitev človekovih pravic in državljanskih svoboščin, živijo stalno $\mathrm{v}$ tujini in budno spremljajo oddaje kot so «Pričevalci» in «intervju-ji», ki jih vodi dr. Jože Možina («Časnik») [Mam nadzieję, że kilka dni temu chodziło jedynie o błąd techniczny. A przynajmniej takie wytlumaczenie podano po interwencji, gdy zagranica straciła dostęp do programu Lidiji Drobnič. Wielu potomków ofiar ze zewidencjonowanych wojennych i powojennych grobów masowych, a także innych przejawów łamania praw człowieka, mieszka za granicą i ogląda takie programy jak «Pričevalci» i «interviuji», które prowadzi dr Jože Možina]; 
(5) Zgodilo se je preveč šokantno odkritje, da bi lahko kar molčali. Toda politiki $\mathrm{z}$ leve strani političnega spektra drugačnega pristopa niso poznali ( $\ll$ Domovina») [Odkrycie było zbyt szokujące, aby móc je przemilczeć. Jednak politycy z lewej strony spektrum nie znali innego podejścia].

Znamienny jest także fakt, iż oba portale przypomniały decyzję władz Lublany o niepochowaniu szczątków zastrzelonych Romów na cmentarzu Žale, podczas gdy zwykle media te nie wypowiadają się przychylnie o społeczności romskiej. O kwestii pochówku Romów mowa jest także w „Demokraciji”, lecz jest to jedynie wątek poboczny, gdyż artykul skupia się na danych statystycznych dotyczących mogił i podkreślaniu, że problem szczątków nie został rozwiązany, ponieważ ofiary nadal nie mają grobów:

(6) vsaj načeloma bi vse žrtve imele pravico do spomina in groba, kjer mrtvi ne bi bili več talci ideologije, ampak bi bili predmet ustrezne državne skrbi [przynajmniej dla zasady wszystkie ofiary powinny mieć prawo do pamięci i grobu, gdzie martwi nie byliby zakładnikami ideologii, lecz przedmiotem troski państwa].

Artykuł ten obfituje w obrazowe określenia, np. krvava revolucija, pretresljivi dokumentarni film, zverinsko pobiti, które łatwo docierają do czytelników, wpływając na ich odczucia lub gruntując je. Ponieważ portal „Demokracija” pozwala na komentowanie, pod artykułem można przeczytać emocjonalnie nacechowane wypowiedzi czytelników (zapis oryginalny):

(7) Komunistični klavci, upam da se boste cvrli v peklu. Nič jim ne pride do živega! [Komunistyczni rzeźnicy, mam nadzieję, że będziecie się smażyć w piekle. Nic ich nie rusza!];

(8) 700 morišč in stotisoči pobitih Slovencev in Slovenk ter ljudi iz Balkana jih ne gan! Morda jim bo Solkan sesul krvavo strategijo zamolčevanja in napadnja žrtev ter svojcev! [700 grobów masowych i setki tysięcy zamordowanych Słoweńców i Słowenek oraz ludzi z Bałkanów ich nie obchodzą! Może Solkan popsuje ich krwawą strategię przemilczenia i atakowania ofiar i swoich!].

Powyższe komentarze są przykładami jednokierunkowego sposobu myślenia czytelników, co jest charakterystyczne dla uwag zamieszczanych w tygodniku „Demokracija”. W pozostałych portalach komentarze są zwykle bardziej zrównoważone, choć niepozbawione emocji:

(9) Bravo! Zelo lepo ste opisali poglede na NOB in ZMAGOVALCE. Pa tudi BEDO častilcev REVOLUCIJE. Če bi TIGR imel vodstvo NOB, sigurno ne 
bi šel v bratomorno vojno. Veliko manj grobov bi bilo v Sloveniji. Doma pa bi ostala INTELIGENCA, ki se s KOMUNIZMOM ni strinjala. ( $\ll$ Domovina») [Brawo! Bardzo dobrze opisaliście NOB i ZWYCIĘZCÓW. A także GŁUPOTĘ czcicieli REWOLUCJI. Gdyby TIGR kierował NOB, na pewno nie doszłoby do bratobójczej wojny. Dużo mniej by było grobów w Słowenii. Zostałaby INTELIGENCJA, która nie zgadzała się z KOMUNIZMEM!];

(10) Noben zmagovalec ne dela proti sebi!! Na koliko partizanskih grobov bi se šli pokloniti domobranski zmagovalci(če bi bili) danes!!! Na kateri slovesnosti v spomin partizanskih žrtev je bil Janša kot predsednik vlade???? («Domovina») [Żaden zwycięzca nie działa przeciw sobie!! Na ile partyzanckich grobów domobranci poszliby złożyć cześć (gdyby zwyciężyli)!!! Na których uroczystościach upamiętniających partyzantów byłby Janša jako premier???];

(11) Rehabilitirati mrtve narodne izdajalce (s kitkami) pomeni, da ostane še samo revolucija. Za nekatere ta ni sporna. Je pa sporna za Evropo in svet, kjer smo zapisani kot Stalinovi vazali. Boj proti Nemcem je razlog, zaradi katerega je stopil narod v OF in NOB. Pravi cilj za KP pa REVOLUCIJA, ki se pokaže v vsem svojem sijaju delno med vojno, popolnoma pa po vojni («Domovina»). [Rehabilitacja martwych zdrajców narodu (z warkoczyka$\mathrm{mi})$ oznacza, że zostaje tylko rewolucja. Dla niektórych bezsporna. Ale jest sporna dla Europy i świata, gdzie zapisaliśmy się jako wasale Stalina. Walka z Niemcami jest powodem, dla którego naród wstąpił do NOB i OF. Prawdziwym celem KP była REWOLUCJA, która pokazała się w pełnej krasie częściowo podczas wojny i całkowicie po wojnie];

(12) Zgodovina je za nami. Skrb vzbuja pa dejstvo, da ljudje z ideologijo, ki je bila osnova za te poboje vodijo našo državo. Nadkancler vlade je predsednik skrajne Levice. Iz zgodovine se je potrebno kaj naučiti, še človekov prijatel osliček gre samo enkrat na led («Delo»). [Historia jest za nami. Niepokojący jest fakt, że ludzie wyznający ideologię, która była podstawą tych morderstw kierują naszym państwem. Nadkanclerzem rządu jest przewodniczący skrajnej Lewicy. Z historii należy się uczyć, tylko raz popełnia się jeden błąd].

(13) Naj gre dežman še malo tiste grobove poiskati,ki so jih povzročili domobrani in črna roka («Delo»). [Niech dežman pójdzie poszukać tych grobów, które powstały za sprawą domobranów i czarnej ręki].

Drugim tekstem opierającym się na barwnych, pobudzających wyobraźnię obrazach jest zamieszczony w tygodniku „Reporter” artykuł Čas ni pozdravil ran, temveč jih je celo poglobil („Czas nie zabliźnił ran, lecz je pogłębił”). Trudno 
przejść obojętnie obok opisu plastikowych skrzynek i worków pełnych ludzkich szczątków, informacji o warkoczach 30 młodych Słowenek:

(14) gre v primeru odkopanih žrtev za zadnjo skupino okoli 800 Slovencev, med njimi 30 mlajših Slovenk z gostimi kitami [w tym przypadku chodzi o grupę 800 Słoweńców, wśród których było 30 młodych Słowenek z grubymi warkoczami]

oraz o dzieciach i inwalidach wśród ofiar:

(15) žrtev, ki se je z roko oklepała proteze na nogi [ofiara, która ręką obejmowała protezę na nodze].

Aby dopełnić obrazu, autor tekstu opisuje śmierć zakopanych żywcem ofiar:

(16) žrtve so umirale v hudih mukah, dokler se niso povsem gole in odvržene ena na drugo zadušile [ofiary umierały w strasznych męczarniach, dopóki się nie udusily, całkowicie gołe i rzucone jedna na drugą

i porównuje czystki do Srebrenicy i działań Stalina:

(17) Tito je bil leta 1945 morilsko celo bolj učinkovit kot Stalin. Prav Huda Jama je neprekosljiv spomenik najhujše morije po drugi svetovni vojni v Evropi. Celo Srebrenica je po voluminu pobijanja vsaj desetkrat manjša, kot je bilo v Sloveniji pobijanje v letu 1945 [W 1945 Tito był skuteczniejszym zabójcą niż Stalin. Huda Jama jest niezaprzeczalnym pomnikiem największego ludobójstwa po II wojnie światowej w Europie. Jeśli chodzi o objętość, nawet Srebrenica była przynajmniej dziesięciokrotnie mniejsza niż zabójstwa w Słowenii w 1945].

Zadaje ponadto retoryczne pytanie o słuszność nazywania frontu „narodowowyzwoleńczym":

(18) ali je lahko vojska označena za osvobodilno, če pobija lastne državljane, in ali je bil še kje v svetu osvoboditelj, ki je v pičlih dveh mesecih pobil kar odstotek lastnega prebivalstva? [czy wojsko można określić narodowowyzwoleńczym, jeśli zabija własnych obywateli, i czy gdziekolwiek na świecie był oswobodziciel, który w dwa miesiące zabił cały procent własnej ludności?].

Następnie autor przechodzi do konkluzji: potrzebna jest zmiana sił politycznych, które zajmą się historiografią XX wieku, ponieważ historia musi być pisana także z perspektywy ofiar. Należy także usunąć komunistyczne mity z programu nauczania i zakazać noszenia symboli rewolucyjnych. Temat rocznicy odkrycia w Hudej Jamie znów staje się więc pretekstem do dyskusji o komunizmie. 
Jedynym artykułem, w którym dość rzetelnie przedstawiono historię masowego grobu, jest ten zamieszczony w portalu „e-Maribor” - autor w skrótowy sposób opisał, co i dlaczego się wydarzyło, nie zrezygnował jednak z silnie nacechowanego słownictwa, co można uznać za element manipulacji (o technikach manipulacji pisał m.in. Kossecki 2001):

(19) Psihopatski um komandantov; se jim ni ljubilo kopati grobov; grozota, s katero se državna oblast ne želi soočiti [Psychopatyczne rozumowanie komendantów; nie chciało im się kopać grobów; zgroza, z którą władza nie chce stanąć twarzą w twarz].

W dzienniku „Delo” zamieszczono zaś suche informacje na temat współczesnej sytuacji (czym zajmuje się komisja ds. masowych grobów, ile mogił odkryto, ile pieniędzy przeznaczono) oraz fragmenty wypowiedzi Dežmana o tym, że państwo po macoszemu traktuje kwestię pochowania szczątków.

\section{Wnioski}

II wojna światowa i zdarzenia powojenne są w Słowenii relacjonowane głównie przez media prawicowe („Demokracija”, „Reporter”, „Domovina”, „Časnik”, „Nova 24”) lub centroprawicowe („e-Maribor”). Media lewicowe i centrolewicowe (np. „Mladina”, „Delo”, „Dnevnik”) po temat ten sięgają rzadziej - w przypadku rocznicy odkrycia masowego grobu w Hudej Jamie jedynie dziennik „Delo” zamieścił na swym portalu dwa długie artykuły. Dominującym dyskursem jest więc ten prawicowy, opierający się na przedstawianiu Frontu Wyzwoleńczego (lub komunistów, partyzantów czy samego Tity) jako bezwzględnych oprawców, którzy z zimną krwią zamordowali tysiące niewinnych ludzi, w tym kobiet i dzieci. $\mathrm{W}$ dyskursie tym nie ma miejsca na pokazanie motywacji oprawców oraz przyznanie, że druga strona konfliktu kolaborowała $\mathrm{z}$ okupantem. Ponadto temat zbiorowych mordów jest dla prawicowych mediów pretekstem do wyrażenia negatywnej opinii na temat lewicowej frakcji słoweńskiej polityki, mediów czy nawet całego społeczeństwa.

\section{Bibliografia}

Burke P. (1989), History as Social Memory, [w:] T. Butler (red.), Memory: History, Culture and the Mind, Oxford, s. 97-113.

Burke P. (2008), What is Cultural History?, Malden. 
Halbwachs M. (2008), Społeczne ramy pamięci, Warszawa.

Kossecki J. (2001), Elementy nowoczesnej wiedzy o sterowaniu ludźmi. Socjotechnika, socjocybernetyka, psychocybernetyka, Kielce.

Król M. (2008), Wstęp do wydania polskiego, [w:] M. Halbwachs, Społeczne ramy pamięci, Warszawa, s. XIII-XXXV.

Misztal B. (2003), Theories of Social Remembering, Maidenhead.

Nora P. (2010), Czas pamięci, „Res Publica Nowa”, nr 200, s. 134-142.

\section{Źródła prasowe}

„Časnik”: https://www.casnik.si/grobisce-morisce-huda-jama/ (dostęp: 25.01.2020). „Delo”: https://www.delo.si/novice/slovenija/ob-10-obletnici-odkritja-hudejame-nadaljevanje-urejanja-grobisca-155938.html (dostęp: 25.01.2020) oraz https://www.delo.si/novice/slovenija/slovenija-ne-skrbi-za-vojnagrobisca-155582.html (dostęp: 25.01.2020).

„Demokracija”: http://www.demokracija.si/slovenija/danes-10-obletnicaodkritja-hude-jame-strogo-varovane-skrivnosti-komunisticnih-zlocincev. html (dostęp: 25.01.2020).

„Dnevnik”: https://www.dnevnik.si/tag/huda\%20jama (dostęp: 25.01.2020). „Domovina”: https://www.domovina.je/10-let-od-pojava-drugorazredne-teme/ (dostęp: 25.01.2020).

„e-Maribor”: https://e-maribor.si/10-let-3-marca-2009-so-ljudje-prvic-povojni-prisli-do-morisca-in-grobisca-v-hudi-jami/ (dostęp: 25.01.2020).

„Nova 24”: https://nova24tv.si/lokalno/jame-polne-cloveskih-trupel-fojbekomunisticnih-zlocinov-na-slovenski-strani-meje/ (dostęp: 25.01.2020). „Reporter”: Čas ni pozdravil ran, temveč jih je celo poglobil, „Reporter”, 10, s. 44-47.

Katarzyna Bednarska

\section{MEDIA AND COLLECTIVE MEMORY - THE ANALYSIS OF MODERN SLOVENIAN MEDIA DISCOURSE ABOUT MASS GRAVES IN HUDA JAMA}

(Summary)

This article analyzes media discourse and the collective memory of Slovenes regarding the period of World War II and several post-war years. On the basis of media reports about the tenth anniversary of the discovery of mass graves in Huda Jama, it will be presented how the World War II was inscribed in the collective memory of Slovenes and how war events cause ideological divisions of Slovenian society.

Key words: media discourse, collective memory, discourse analysis, historical discourse, Slovenia 